\title{
Can South-South trade Liberalisation Stimulate North-South Trade?
}

\author{
Marco Fugazza \\ United Nations Conference on Trade and Development, Switzerland \\ Frédéric Robert-Nicoud \\ London School of Economics, and CEPR, UK
}

\begin{abstract}
This paper uses a combination of Ethier (1982) and Melitz's (2003) models to show that liberalizing trade among developing countries, so-called South-South trade, could contribute to improve the access to international markets of developing countries' would-be exporters. Lower trade barriers among developing countries has the effect of lowering the price of intermediate inputs and eventually allows exporters in those countries to serve international markets. We also compare unilateral and multilateral South-South trade liberalization and find that the latter unambiguously reduces the price of intermediates in all participating countries, whereas the former has ambiguous effects.
\end{abstract}

- JEL classification: F12, F13, F15

- Keywords: South-South Trade, Market Access, Input-output linkages, Value chain

\section{Introduction}

Trade among developing countries, so-called South-South trade, has been rising significantly in the last two decade (UNCTAD, 2004). At the beginning of the 1980 's trade among developing countries represented one fourth of their total trade.

\footnotetext{
*Corresponding address: UNCTAD, Palais.des Nations, CH-1211 Geneva 10, Switzerland. Phone: +4122 917772. Fax: ++ 9070044. E-mail: marco.fugazza@unctad.org

(c2006-Center for International Economics, Sejong Institution, All Rights Reserved.
} 
In 2003, this share went up to around 40 per cent. However, there is still significant scope for pushing forward South-South trade liberalization. Indeed, around 70 per cent of the tariffs faced by developing country exporters are applied by other developing countries. Limited access to international markets, and in particular to developed countries markets, are often presented as a strong impediment to developing countries export performance, especially in the context of trade negotiations at the World Trade Organization since the launching of the Doha round. ${ }^{1}$ However, there is a growing determination of Developing countries to promote further trade liberalization among them as shown by the increasing effectiveness of the regional trade agreements that have proliferated over the last decade ${ }^{2}$ in the Southern hemisphere. This determination has been also clearly stated at the eleventh session of the United Nations Conference on Trade and Development held in June 2004 (see UNCTAD 2004). In particular, the third round of GSTP ${ }^{3}$ negotiations was launched during this eleventh session and the members insisted on their conviction that "an ambitious package of trade liberalization commitments would promote economic complementarities among the Participants especially at the interregional level". ${ }^{4}$ Using economic jargon, we might say that many representatives and negotiators view regional integration as a way to reduce the cost of intermediates (for instance by allowing countries to specialize in specific intermediate goods according to their comparative advantage) which would, in turn, make it easier for them to produce final goods and serve global markets. A practical example is the recent establishment of "competitiveness forums" ("Foros de Competitividad") in MERCOSUR countries. The officially stated objective of the first forum dealing with wooden goods and furniture is to "identify segments of the production chain that can complement each other in industrial processes among MERCOSUR countries and allow an increase in the competitiveness of regional

\footnotetext{
${ }^{1}$ See the Doha Ministerial Declaration (WT/MIN(01)/DEC/W/1), Ministerial Conference, Fourth Session, Doha, 9-14 November 2001, adopted on 14 November 2001.

${ }^{2}$ Among the recent trade arrangements, India and the MERCOSUR signed a preferential trade agreement on January 25, 2004.

3Global System of Trade Preferences among developing countries. It envisages preferential trade arrangements among 43 developing countries and accession will be opened to China and the group of 77.

${ }^{4}$ Excerpt from São Paulo Declaration reported in UNCTAD/PRESS/PR/SPA/2004/010 (available at http:/ /www.unctadxi.org/templates/Press 927.aspx)
} 
products in third countries' markets". 5

The primary purpose of our paper is to support and qualify the view that developing countries' export performance and access to international markets are likely to be lifted by substantial liberalization of trade among them. We believe it is as important to understand what policy makers are thinking about when they are negotiating as it is for them to understand the economic relevance of the policies they are advocating. In a framework in which Southern firms buy intermediate inputs from other Southern firms, South-South trade liberalization logically lowers prices for final good producers. As a result, Southern final good producers are more likely to penetrate Northern markets.

After having laid out the core argument, we move on to assessing the various impacts of unilateral and multilateral trade liberalization among Southern countries. In particular, we argue that even if multilateral trade agreements are likely to dominate unilateral trade liberalization ${ }^{6}$ (in a sense that we make clear in the text), unilateral trade liberalization is likely to dominate the status quo. The main reason behind the first result is that elements of strategic trade policy provide weak incentives to liberalize trade unilaterally because of the Price Lowering Protection (PLP hereafter) effect, which implies that an increase in unilateral protection may lower the domestic price level (Venables, 1987). This introduces a bias against unilateral trade liberalization. However, the PLP effect disappears when trade is liberalized multilaterally. This result then would support the creation of preferential trade agreements. The main reason behind the second result is that the PLP effect is not robust (see Baldwin et al. 2003, chapter 12). Therefore, under reasonable circumstances, unilateral trade liberalization should indeed provide cheaper intermediate inputs and, in turn, make it easier for final good exporters to penetrate international markets.

The rest of the paper is organized as follows. The next section presents our modelling strategy and relates it to the existing literature. Section 3 sets up the theoretical framework with particular attention paid to the specificities of the upstream and downstream sectors. Section 4 assesses the possible impact of SouthSouth trade liberalization, focusing on the elements that would make a bilateral liberalization desirable. Finally, section 5 discusses the results of the model and its

\footnotetext{
${ }^{5}$ See MERCOSUR/LII GMC/DI No. 19/03 (available at http://www.mercosur.org.uy/paginalesp.htm)

${ }^{6}$ Multilateral trade agreements can also allow to eliminate terms-of-trade effects between members as e.g. Bagwell and Staiger (2002) argue.
} 
possible implications for policy and concludes.

\section{Modelling Strategy and Review of the Literature}

In order to qualify the role of preferential trade agreements among Southern countries in the access international markets of their exports, we use a model of international trade which combines the Dixit-Stiglitz setting with heterogeneous firms a-la Melitz (2003), with input-output linkages in the wake of Venables (1996) and Ethier (1982) and where southern final product producers face a 'beachhead cost' and a variable cost of exporting on international markets (Baldwin, 1988; Melitz, 2003). In this setting, not all firms export to the world markets -only the most efficient ones do- and no firm exports if intermediates are too expensive.

Our approach comes within the framework of the firm-centred new-trade-theory and adds to the standard Melitz model the integration of input-output linkages. The recent availability of widespread firm-level data has permitted to uncover a variety of facts that were buried in more aggregated data. Sunk market entry costs and heterogeneity of firms are the two main features that these empirical studies emphasize (see Tybout 2000 for a survey), as well as the recent theoretic framework due to Melitz (2003). ${ }^{7}$ In particular, Bernhard and Jensen, 1999a,b) show that the most efficient U.S. firms self-select into export markets. . Using data from Colombian plants producing industrial chemicals, Das, Roberts and Tybout (2004) report that entry costs for plants breaking into foreign markets are substantial. Moreover, a survey of Columbian manufacturers, as reported in Roberts and Tybout (1997), reveals that impediments to exporting, as such as information deficiencies, are a significant element to a firm's decision to break into a foreign market or not. The combination of firms' productivity heterogeneity and sunk cost to export implies that firms self-select in an export market. Existing empirical evidence for developing countries tends to support this argument. Using plant-level panel data from Colombia, Mexico and Morocco, Clerides, Lach and Tybout (1998) find very little evidence that past exporting improves performance but rather that more productive firms self-select into export markets. Similar conclusions are reached for instance in Aw, Chung and Roberts (2001) for Taiwan and in Muendler

\footnotetext{
${ }^{7}$ Together, these facts also help explain why the distribution of export volumes are truncated and why there are a lot of zeroes in three-dimensional matrices of exports by sector, importing country and exporting country (more generally, numerous country pairs do not trade at all with each other; see Helpman, Melitz and Rubinstein, 2004, for a "gravity equation with holes").
} 
(2001) for Brazil. Self selection is also found to be a significant explanation of firms export status, although not exclusive, in Hahn (2004) for Korea, HallwardDriemeier, Iarossi and Sokoloff (2002) for a panel of five East Asian countries (Indonesia, Korea, Malaysia, The Philippines and Thailand), in Van Biesebroeck (2003) for a panel of nine African countries (Burundi, Cameroon, Cote d'Ivoire, Ethiopia, Ghana, Kenya, Tanzania, Zambia and Zimbabwe), and "Yaşar" and Helson (2003) for the Turkish apparel and motor vehicles and parts industries. The predictions of our model are also in line with Pavcnik's (2002) results from plantlevel data on Chilean manufacturers. In particular, the author finds that trade liberalization causes resources reshuffling from less to more productive producers for the plants in the export-oriented sectors, and as a consequence aggregate productivity grows.

In a context in which would-be exporting firms have to incur a fixed cost of exporting, we show that lowering variable trade restrictions (like tariffs) among southern countries could contribute to improve the access to international markets of southern producers of final goods. The intuition for this result is uncomplicated: when restrictions applied to south-south trade are lowered, the price of intermediate inputs falls and producers of final goods are able to extract larger profits that would eventually allow some of them to cover the cost of exporting on international markets.

This simple argument has received only scarce attention either from a theoretical or an empirical point of view. Instead, most of the existing studies are concerned by the trade creation versus trade diversion effect of Regional Trade Agreements. For instance, Venables (2003) reaches the conclusion that benefits from SouthSouth trade agreements are likely to be small and generate trade diversion. In other words, production patterns in Southern countries induced by the trade agreement are likely not to correspond to their true underlying comparative advantage. The logic of the argument is rooted in neoclassical trade theory, with patterns of comparative advantage being exogenous and immutable. In other approaches, like the so-called 'New Economic Geography' (Fujita, Krugman and Venables, 1999), cumulative causation mechanisms at the core of the formation of industrial clusters sort of 'endogenises' the comparative advantage variable. In such a setting, the qualification of the impact of RTAs goes beyond the trade creation versus trade diversion dimension. For instance, combining the standard features of the new trade theory and forward and backward linkages among firms, Puga and Venables $(1997,1998)$ find more mitigated results, although they also argue that North- 
South preferential trade agreements are likely to offer better prospects for Southern countries, including for non participating ones.

As mentioned previously there is no empirical work, to our knowledge, specifically looking at the impact that preferential trade agreements among southern countries can have on access to international markets of the participating countries final products. However, empirical evidence for the first half of our mechanism can be found in Madani (2001) who investigates the role played by imported inputs in industrial growth in Singapore, the Philippines and Malaysia. The author finds that the variety of intermediate imports originating from regional partners affects positively and significantly output growth in a large set of industries. Nevertheless, nothing is said about the impact on exported products processing and destination (which forms the second half of our story). Other related empirical work includes Sangunietti, Taistaru and Martincus (2004), who attempt to asses the impact MERCOSUR on industrial development across member countries. Their results support to some extent Venables' (2003) theoretical predictions in that trade liberalization among MERCOSUR countries appears to favour a restructuring of production patterns along the lines dictated by regional comparative advantage. They also find some evidence of a weakening of economic activity agglomeration forces as predicted by the Puga and Venables (1998) model.

Empirical studies of the impact of preferential trade agreements on intra-bloc and extra-bloc trade indicate, albeit not systematically, a positive impact on intrabloc trade but an uncertain overall impact (see Soloaga and Winters (2001) and references therein). The World Bank (2004) uses an augmented version of the gravity model to capture overall exports of a member of a particular set of preferential trade agreement. By doing so, World Bank economists aim to assess the extra exports of the countries that are part of the agreement due to the agreement itself. Their results are mitigated, showing the possibility of both negative and positive impact depending on the agreement under consideration. The methodology contains various caveats that eventually do not to allow the authors to isolate the impact of a specific preferential trade agreement from unilateral or multilateral trade policies.

\section{A Simple Partial Equilibrium Model}

In order to keep the analysis simple and concise, the model is presented in a partial equilibrium form that allows us to focus on the crux of our argument. 
Figure 1. A stylised world economy

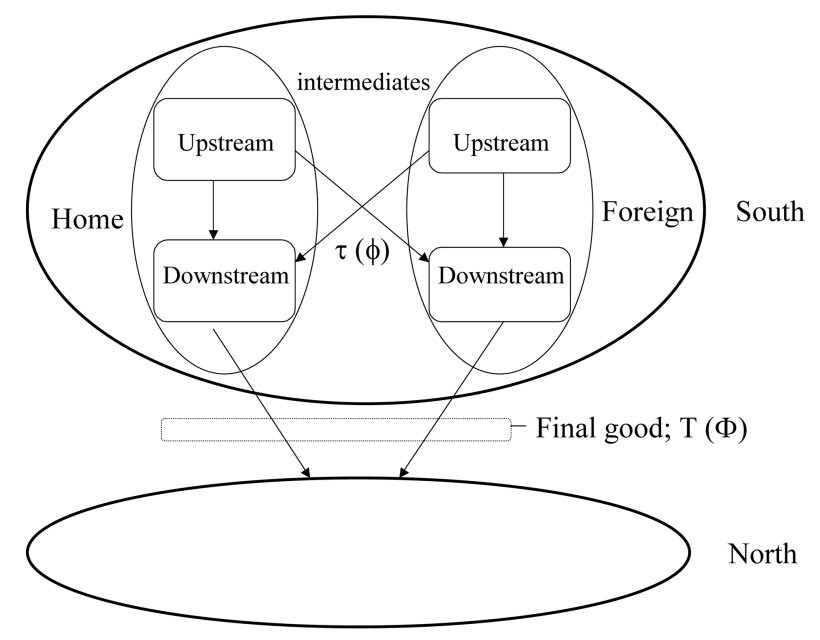

Southern countries' representatives care a lot about access to Northern markets for their manufacturing products; here, we rationalize this argument but do not take sides on wider debates regarding trade creation vs. trade diversion nor do we convey any welfare analysis.

The world is made of two zones, North and South; the latter is small vis-à-vis the former in a sense that we make clear in the sequel. There are two identical economies in the South, Home and Foreign (we relax the assumption of identical countries in the following section). Figure 1 describes this stylised economy.

We focus our interest on the manufacturing sector in the Southern countries, which we describe next. In each country, Manufacturing comprises two monopolistically competitive sectors: 'Upstream' and 'Downstream', with the former producing intermediates for the latter. Formally, we present only the case where Southern firms export target is the Northern Markets (in general decisions regarding the Northern markets should interact with decisions regarding Southern markets, but we take the magnitude of these interactions to be of second order). However, as discussed below a straightforward extension of the model allows the inclusion of other potential export markets.

\section{A. Upstream sector}

Upstream uses primary factors capital $K$ and labour $L$. Labour, which we chose as the numéraire, is inelastically supplied to the Upstream sector but there is a fixed supply of $K\left(K^{*}=K\right)$ units of upstream-specific capital in Home (Foreign). The cost 
function of a typical Home upstream supplier is

$$
C(x)=\pi+w \beta x
$$

where $p$ is the price of $K, w$ is the wage, $x$ is upstream output and $\beta$ is the labouroutput coefficient. Variables pertaining to Foreign are symmetric and superscripted with asterisks when necessary. Note that the foregoing cost function exhibits increasing returns to scale at the firm level (Flam and Helpman, 1987). Intermediate inputs are differentiated and to each variety corresponds a unique firm and each firm produces only one variety.

The downstream sector combines all available varieties into a composite intermediate good. The elasticity of substitution between any pair of intermediates is parameterised by $\sigma>1$ (Dixit and Stiglitz, 1977; Ethier, 1982 ).

Trade in intermediates between Home and Foreign is impeded by iceberg trade costs (Samuelson, 1954), that is, $\tau>1$ units of the good produced in Foreign need to be shipped if one unit is to arrive in Home. As a result of the foregoing assumptions (Dixit-Stiglitz monopolistic competition and Samuelsonian transportation costs), profit-maximising behaviour in the upstream sector yields:

$$
P_{r s}(j)=\left\{\begin{array}{l}
\frac{\beta}{1-1 / \sigma} w, r=s \\
\tau \frac{\beta}{1-1 / \sigma} w, r \neq s
\end{array} r, s=\right.\text { Home, Foreign }
$$

where $p_{\mathrm{rs}}$ denotes buyer price; we have adopted the notational convention $p_{f r o m, t o}$. We can chose units with which we measure upstream output so that $\beta=1-1 / \sigma$ which implies that $\mathrm{p}_{\mathrm{rr}}=1$ and $\mathrm{p}_{\mathrm{rs}}=\tau(s \neq r)$, that is, trade costs are fully passed onto consumers, as is standard in Dixit-Stiglitz monopolistic competition.

To simplify expressions, we assume that the South does not import intermediates from the North (this assumption entails no further loss of generality and could easily be relaxed). Let us define $\phi \equiv \tau^{1-\sigma}$ as 'freeness of trade'; when trade costs are prohibitive then $\phi=0$; when trade costs are nil then $\phi=1$.

Therefore, the price of the composite intermediate good, $P \equiv\left(\int_{j} p(j)^{1-\sigma} d j\right)^{1 /(1-\sigma)}$, can be written as:

$$
P=\Delta^{1 /(1-\sigma)}, P^{*}=\left(\Delta^{*}\right)^{1 /(1-\sigma)} ; \Delta \equiv K+\phi K^{*}, \Delta^{*} \equiv K^{*}+\phi K
$$

Thus, it is immediate that freer trade between Southern countries translates into a 
cheaper intermediate composite for final good producers, that is, $\partial P / \partial \phi<0$. Therefore, we write:

Result 1: Freer south-south trade in intermediates reduces final goods variable production costs in both countries.

Clearly, any South-south trade liberalisation that allows countries to specialise in the production of different kind of intermediates according to neoclassical comparative advantage would yield a similar result.

\section{B. Downstream sector}

The downstream sector uses all available varieties of intermediates. Specifically, we write the (variable) cost function of a typical firm in the downstream sector as

$$
C(\gamma, y, P, w)=\gamma \cdot c(P, w) \cdot y
$$

where $y$ is final output, $P$ is the perfect price index of the intermediate input combo and $\gamma$ is a positive parameter. Upon entry, the firm has to sunk $f$ units of the numeraire (more on this below), which implies that there are increasing returns at the firm level in the downstream sector, too. Parameters $f$ and $\gamma$ capture the magnitude of fixed and variable costs, respectively, and $c(.,$.$) is homogenous of$ degree one in input prices.

Following Eaton and Kortum (2002), among others, we assume that the variable component $\gamma$ is firm-specific. Specifically, $\gamma$ is drawn from a cumulative distribution function $G($.$) with compact support \Gamma \subset \mathfrak{R}_{+_{+}}$. As in Baldwin (1988) and Melitz (2003), firms have to incur the 'beachhead' cost $f>0$ before being able to export to North's market.

North's demand for a typical y variety produced with labour-output coefficient $\gamma$ is equal to

$$
y(\gamma)=A T[q(\gamma)]^{-\varepsilon}, \quad \varepsilon>1
$$

where $q(\gamma)$ is the price, $A$ is a measure of North's market capacity (Helpman, Melitz and Yeaple, 2003) and T>1 is the iceberg transportation cost of the final good. In words, the downstream sector produces final goods that North's consumers combine into a CES composite; the elasticity of substitution between any two varieties from the Downstream sector (produced in North or South) is parameterised by $\varepsilon$. We assume that South is small enough on world markets so 
that its impact on $A$ is negligible. Moreover, firms are atomistic and therefore they consider $A$ as a parameter.

In this setting, it is well known that $q(\gamma)=T c(P, w) \gamma \varepsilon^{\prime}(\varepsilon-1)$ and operating profits are equal to $\pi(\gamma)=\left[T \gamma c(P, w) \varepsilon^{\prime}(\varepsilon-1)\right]^{1-\varepsilon} A / \varepsilon$. In an intertemporal setting where firms die with a Poisson arrival rate $\delta$, the value of a Southern firm that exports to the North is

$$
V(\gamma)=\frac{A}{\varepsilon \delta}\left[T \gamma c(P, w) \frac{\varepsilon}{\varepsilon-1}\right]^{1-\varepsilon}
$$

thus Southern firms enter the North Market if, and only if, $V() \geq$.$f . As a result,$ only the most efficient firms serve North's market (Melitz, 2003). Mathematically, all firms whose variable input component $\gamma$ is lower that some threshold $\gamma^{X}$ export, with

$$
V\left(\gamma^{X}\right)=f \Rightarrow \gamma^{X}=\frac{\varepsilon-1}{\varepsilon T c(P, w)}\left(A^{\prime} \varepsilon \delta f\right)^{1 /(\varepsilon-1)}
$$

Comparative statics on this expression corroborate intuition: final-product firms are more likely to export to the North's market, the lower the domestic price of intermediate inputs $P$ (and thus the lower $\tau$ by Result 1), the larger the North's market capacity and the better the South's access to North's market (the lower T). Therefore, the probability distribution of exporting firms is equal to $G^{X}($.$) on$ support $\Gamma^{\mathrm{X}}$, where

$$
G^{X}(\gamma)=1-\frac{1}{G\left(\gamma^{X}\right)} \int_{\gamma}^{\gamma^{X}} d G(\gamma), \Gamma^{X}=\Gamma \cap\left(0, \gamma^{X}\right]
$$

Of course, if trade barriers - both South-South $\mathrm{t}$ and South-North $\mathrm{T}$ - are too large, then no firm will be able to manufacture final goods tailored to the North's market; this will be the case if $\gamma^{X}<\inf \Gamma$ (in which case $\Gamma^{X}=\varnothing$ ).

As in Melitz (2003) and Hopenhayn (1992), developing a new variety involves some R\&D cost. As in Baldwin and Robert-Nicoud (2006), we model the R\&D sector as perfectly competitive. Developing a new variety costs $f^{R \& D}$ units of the numéraire (labour); the outcome is random in the sense that the R\&D lab is always successful in developing a new variety but it draws a $\gamma$ from $\mathrm{G}$. The value of the patent (gross of beachhead costs) is computed according to (6) ); by free-entry, the 
price of the patent sold to the potential final good producer is then equal to $V($.)-f. This price is zero for those varieties with $\gamma>\gamma^{X}$.

For simplicity, we assume that there are congestion costs of sorts in the R\&D sector (i.e. decreasing returns at the aggregate level) so that $f^{R \& D}$ is a (weakly) convex function of $n$, the total number of Southern producers in sector $Y$, namely

$$
f^{R \& D}=F(n) ; \quad F(0) \equiv F_{0}>0, \quad F^{n}(n) \geq 0, \quad F^{\prime \prime}(n)>0
$$

As a result, free-entry in the R\&D sector implies

$$
\begin{aligned}
F(n) & =\int_{\gamma \in \Gamma^{X}}[V(\gamma)-f] d G^{X}(\gamma) \\
& =\int_{\gamma \in \Gamma^{X}}\left[\left(\frac{\gamma^{X}}{\gamma}\right)^{\varepsilon-1}-1\right] f d G^{X}(\gamma)
\end{aligned}
$$

where the second equality stems from (6) ) and (7) ). Note also that, by the latter expression, the right hand side of (10) ) is decreasing in $f$. As a result, the equilibrium number of firms,

$$
n^{X}=\operatorname{int}\left[F^{-1}\left(\int_{\gamma \in \Gamma^{X}}\left[\left(\frac{\gamma^{X}}{\gamma}\right)^{\varepsilon-1}-1\right] f d G^{X}(\gamma)\right)\right]
$$

is increasing in the probability of success in the R\&D sector (and thus increasing in $\gamma^{X}$ ) and decreasing in $\mathrm{f}$. Given the comparative statics on $\gamma^{X}$ following (7) two results follow.

First, $n^{X}$ is increasing in A (North's market capacity) and decreasing in c(P,w) and $\mathrm{T}$ (transportation and variable production costs, respectively). Since $\mathrm{P}$ is increasing in $\tau, n^{X}$ is decreasing in $\tau$ (increasing in $\phi$ ). Moreover, $n^{X}=0$ if parameters are such that $\Gamma^{X}=\varnothing$. However, even if $\Gamma^{\mathrm{X}}$ is non-empty, $n^{X}=0$ if the probability of success is too small relatively to $F_{0}$, the fixed $R \& D$ cost. Finally, note that $\mathrm{V}(\gamma)$ in $(6)$ is just $1 / \varepsilon \delta$ times the value of sales of the exporting firm with variable cost $\gamma$, thus, provided $\Gamma \neq \varnothing$, the volume of exports is increasing in $\mathrm{A}$ and decreasing in $\mathrm{c}(\mathrm{P}, \mathrm{w})$ and $\mathrm{T}$. In plain words, we write:

Result 2: In those sectors in which freeing South-South trade reduces the price of intermediate inputs, Southern firms are more likely to develop final goods and break into Northern markets. Moreover, the volume of exports is increasing in the 
degree of South-South trade liberalisation in intermediate inputs.

A corollary of this result is the following. Let $F_{0}$ and $\tau^{0}$ be so large that no firm exports; furthermore, let $\tau^{2}$ be substantially lower than $\tau^{0}$ so that some firms export under this new trade regime. Finally, assume that Southern countries liberalize trade in intermediates from $\tau^{0}$ to $\tau^{\prime}$. As a result of this policy, a massive reorganisation in production pattern unfolds in the following sense: Southern final good producers break into third countries markets. This illustrates the desire of policy makers to 'climb up the value chain'. Thus, producers in the South nolonger content themselves with exporting (usually) low-skill labour-intensive intermediates to the North, they can also profitably sell final goods in 'first world' countries as a consequence of participating to a regional trade agreement. In order to qualify this corollary heuristically, consider the following straightforward extension of our framework. Developed and developing economies often impose a 'tariff escalation ${ }^{18}$ on imported goods; a tariff escalation is defined as higher tariffs on final than intermediate goods. More generally, the existence of often stringent technical trade barriers in Northern markets or the necessity for Southern producers to integrate distribution networks to enter those markets impose substantial tariff barriers and/or beachhead costs for Southern firms. In that context, when trade barriers and/or beachhead costs are so large that no R\&D is profitable enough in the South to develop final goods exportable to the North, Home and Foreign specialise in final goods that are exported to the Southern markets only (and, possibly, export intermediates to the North). When Home and Foreign sign a Regional Trade Agreement, then they might be able to export final goods to developed countries.

\section{South-south Trade Liberalization}

Thus far we have rationalised an argument often heard in developing economies' politics: use freer trade on intermediates among them as a tool to export final goods into the world markets. Note that this argument is different from the 'infant industry protection' argument. First, this is an argument about lowering intermediate inputs' cost so as to launch an exporting manufacturing sector. Second, unilateral liberalization may have an ambiguous effect in this respect; hence coordination among developing countries might be called for. In this section, we pursue the

\footnotetext{
${ }^{8}$ See for instance Cernat, Laird and Turrini, (2003) for a qualification of tariff escalation in both developed and developing countries.
} 
logic laid out in the model of the previous section to tackle these issues. To this aim, we need to enlarge the model somewhat -in particular, we need to consider some feedback (or general equilibrium) effects.

\section{A. Unilateral liberalization in intermediate goods}

Trade models based on increasing returns at the firm level and imperfect competition display a seemingly counter-intuitive result: unilateral trade protection can actually lower domestic prices (Venables, 1987). To see how this can be the case, let us make the following thought experiment (Helpman and Krugman, 1989, chapter 7).

Consider some good that could be produced in either Home or Foreign at the same price; the production of this good is characterised by increasing returns (thus there will be a single plant in South); and trading this good is costly. Then it follows that if, say, Home imposes a higher tariff on this good than Foreign then it is relatively more advantageous to produce in the former country and export to Foreign so as to save on the higher tariff. Therefore, the consumer price is lower in the country with the higher tariff.

Albeit with lower dramatic intensity, the same logic prevails with a continuum of goods in Dixit-Stiglitz monopolistic competition models (Venables, 1987). However, this 'Price Lowering Protection' effect (or PLP effect) is not robust to the change of functional forms and to factors that make Home and Foreign not exactly identical, like neoclassical comparative advantage (see Baldwin et al. 2003, chapter 12 , for an extensive analysis). To see why increasing Home's tariff should have an ambiguous effect in general, use (3) to get

$$
\frac{d \ln P}{d \phi}=\frac{1}{(\sigma-1)\left(K+K^{*} \phi\right)}[-K^{*}-\underbrace{\frac{\partial K}{\partial \phi}}_{<0}-\phi \underbrace{\frac{\partial K^{*}}{\partial \phi}}_{>0}]
$$

where f now denotes Home's freeness of trade (Foreign's reads $\phi^{*}$ ). The first term in the square bracket is the direct effect, which is clearly negative (when Home increases its $\phi$ all $\mathrm{K}^{*}$ imported varieties are now cheaper). The two terms that involve partial derivatives illustrate the indirect 'delocation effect' (Baldwin and Robert-Nicoud, 2000): by the same logic as sketched above, albeit less dramatically, the number of varieties produced at Home (respectively in Foreign) 
decreases (increases) with Home's $\phi .^{9}$ It is an artefact of Dixit-Stiglitz monopolistic competition that the net effect is always positive, that is, unilaterally increasing trade openness increases the domestic price index.

We now turn to the determination of $\mathrm{K}$ and $\mathrm{K}^{*}$. Let $\mathrm{E}$ and $\mathrm{E}^{*}$ denote the expenditure on intermediates in Home and Foreign, respectively. With $\mathrm{K}$ and $\mathrm{K}^{*}$ upstream firms in Home and Foreign, respectively, operating profits are given by:

$$
\pi=\frac{E}{\sigma \Delta}+\phi \frac{E^{*}}{\sigma \Delta^{*}}, \pi^{*}=\phi^{*} \frac{E}{\sigma \Delta}+\frac{E^{*}}{\sigma \Delta^{*}}
$$

where $\Delta^{=} k+\phi^{*} k$ and $\Delta^{*}=\phi K+K^{*}$ (that is, we allow $\phi$ and $\phi^{*}$ to differ). Capital is invested until the value associated with the upstream firms is equal to the fixed cost of developing a new variety of intermediate good, call it $\mathrm{f}^{\mathrm{U}}$. Assuming that upstream firms die at the same rate as downstream firms, we get $\mathrm{V}=\pi / \delta$ and $=\mathrm{V}^{*}=\pi^{*} / \delta$. Free-entry then implies $\mathrm{V}=\mathrm{V}^{*}=\mathrm{f}^{\mathrm{U}}$ in any interior steady state. Let $s_{K} \equiv K^{\prime}\left(K+K^{*}\right)$ and $K^{s} \equiv K+K^{*}$; Solving for $\mathrm{s}_{\mathrm{K}}$ and $\mathrm{K}^{\mathrm{S}}$, we get :

$$
s_{K}=\frac{1}{2}\left[1-\frac{\phi-\phi^{*}}{(1-\phi)\left(1-\phi^{*}\right)}+\frac{\left(2 s_{E}-1\right)\left(1-\phi \phi^{*}\right)}{(1-\phi)\left(1-\phi^{*}\right)}\right], K^{S}=\frac{E^{S}}{\sigma \delta f^{U}}
$$

where $s_{E} \equiv E^{\prime}\left(E+E^{*}\right)$ and $E^{S} \equiv E+E^{*}$. Two aspects of the first expression above are noteworthy. First, the Home Market effect (Krugman 1980) brings a large country advantage: when trade barriers are the same in both countries $\left(\phi^{*}=\phi\right)$, then the larger countries holds a more than proportional share of firms and thus is a net exporter of intermediates (formally, $\phi=\phi^{*}$ and $s_{K}<1 / 2$ imply $s_{E}<s_{K}$ ). Second, the closest of the two countries gets a larger share of upstream industry (that is, $\partial s_{K} /$ $\partial \phi<0)$. This, together with the fact that $K^{S}$ is constant, confirms the signs of the partial derivatives in (12) Standard algebra then reveals that the model displays the PLP effect, namely, $\partial \ln \mathrm{P} / \partial \phi>0$. Indeed, (12) ) evaluated at $\phi^{*}=\phi$ to simplify the expression (this is without loss of generality) yields:

$$
\left.\frac{\partial \ln P}{\partial \phi}\right|_{\phi^{*}=\phi}=\frac{s_{E}}{(\sigma-1)\left[s_{K}+\left(1-s_{K}\right) \phi\right]} \frac{\phi}{1-\phi}>0
$$

Result 3: Unilateral liberalisation has ambiguous effects on the price index and

\footnotetext{
${ }^{9}$ We specify below the general equilibrium mechanism whereby $\mathrm{K}$ and $\mathrm{K}^{*}$ can vary. For now, it suffices to claim that this is the case and show it later.
} 
thus on the possibility to export final goods to the North's market.

Result 3 implies that if governments tried strategically to decrease the domestic price index of intermediates they would face a typical prisoner's dilemma. Indeed, it is a dominant strategy to set $\phi$ (respectively $\phi^{*}$ ) as low as possible, that is, to impose prohibitive trade barriers.

\section{B. Multilateral liberalization in intermediate goods}

Although result 3 indicates that there is a bias against unilateral liberalization, it would be optimal to jointly liberalize and set $\phi$ (respectively $\phi^{*}$ ) as high as possible.

In our framework, if the two countries could sign a RTA that imposes $\phi=\phi^{*}$, then symmetric trade liberalization lowers the price index in both countries. Indeed, imposing $\phi=\phi^{*}$ and taking the derivative with respect to $\phi$ yields:

$$
\left.\frac{\partial \ln P}{\partial \phi}\right|_{R T A}=\frac{s_{E}}{(\sigma-1)\left[s_{K}+\left(1-s_{K}\right) \phi\right]}<0
$$

When countries chose the same $\phi$, the larger country will attract a more than proportional share of industry (as a manifestation of the Home market effect) and this effect will be magnified by freer South-South trade (Krugman 1980, Baldwin et al. 2003). It is worth stressing, however, than the price index falls in both countries (it falls faster in the largest one). Nevertheless, the de-location effect is often perceived as a bad thing politically and this concern is often recognised by large countries. For instance, although the ASEAN Free Trade Area (AFTA) commits all members to the removal of all barriers to intra-regional trade, ASEAN recognizes differences between the levels of development and degrees of economic openness of its members. As a consequence, newer members - Cambodia, Laos, Myanmar and Vietnam- are given temporary special and differential treatment ${ }^{10}$.

Baldwin and Robert-Nicoud (2000) show how RTAs can be tailored to avoid the delocation effect and argue that some RTAs look as if they had been designed to fulfil this aim. Specifically, reciprocal trade liberalisation could be tailored so that $\mathrm{s}_{\mathrm{K}}$ remains constant while $\phi$ and $\phi^{*}$ are increased. Specifically, assume that both countries agree on a $\phi$ and then chose a $\phi^{*}$ such that $\mathrm{s}_{\mathrm{K}}=\mathrm{s}_{\mathrm{E}}$, that is, each country's industry share remains at its autarky level (it can then be shown that $\phi^{*}$ is an

\footnotetext{
${ }^{10}$ See "Southeast Asia - A Microcosm of the Developing World", statement by R. C. Severino (former Secretary-General of ASEAN) at the $51^{\text {st }}$ session of the UNCTAD Trade and Development Board, Geneva, October 2004 (as reported in http://www.unctad.org/en/docs/tdb51d8vol1_en.pdf).
} 
increasing function of $\phi$ ).

In this case, the last two terms in the square bracket of (12) vanish and thus

$$
\left.\frac{\partial \ln P}{\partial \phi}\right|_{\phi^{*}: s_{K}=s_{E}}=\frac{1-s_{E}}{(\sigma-1)\left[s_{K}+\left(1-s_{K}\right) \phi\right]}<0
$$

In short, reciprocal trade liberalisation would avoid the harmful effects of unilateral strategic location policies.

Result 4: In contrast to unilateral trade liberalization, reciprocal trade liberalisation unambiguously reduces the price index and facilitates the export of final goods to the North's market.

Result 4 provides in itself some rationale for coordinated South-South trade liberalisation as opposed to unilateral trade liberalization. In other words, a SouthSouth regional trade agreement could act as a cooperation device.

\section{Concluding Remarks}

Recently, many policy leaders in developing countries have expressed a strong political willingness to strengthen and deepen South-South trade liberalization and economic cooperation. One of the argument often heard is that, by lowering production costs of final good producers, these could break into world markets and generate more value added at home. It is well known that doing so might generate trade diversion (Venables 2003), but the conditions under which such a policy might be successful -be it economically meaningful or not- have been mostly ignored by mainstream economists thus far. This paper provides some economic rationale to this expressed willingness but also some qualification to it.

In particular, we point out that further trade integration among developing countries could indeed contribute to increase the number of final goods produced in Southern countries and the volume of exports of those goods to International/ Northern markets. By lowering the cost of inputs, trade liberalization allows a larger number of final goods producers in developing countries to cover the costs (both fixed and variable) to exporting into international markets. Building on this logic, we then compare unilateral with multilateral liberalization in a South-South dimension. Unilateral liberalization does not necessarily lead to a fall in the price index of intermediate goods because of the Price Lowering Protection effect (Venables 1987). As a consequence, access to international markets for Southern countries final goods may not be improved. However, if countries manage to 
liberalize trade on a multilateral basis, the PLP effect vanishes and the production of final goods becomes less costly for Southern firms in all participating countries. Thus, our results also suggest that a regional South-South trade agreement could serve as a basis for strategic regional economic cooperation.

Arguably the main caveat or our analysis is that our results are obtained in a partial equilibrium context. However, straightforward extensions would allow us to include different market destinations for both intermediate and final goods. This would complicate our description of the equilibrium but our main argument would remain valid; indeed, we are confident that general equilibrium effects would be of second order magnitude in this context.

One natural extension of our analysis would include neoclassical comparative advantage features. ${ }^{11}$ In our set up, the most interesting source of comparative advantage would be rooted in the upstream sector. The main result of such an extension would be to reduce or even wipe out the odd PLP effect (Baldwin et al. 2003). Thus, such an extension would reinforce our main qualitative results. Multilateral liberalization would remain the most desirable scenario.

Interesting avenues for further research in this area are twofold. First, from a theoretical perspective, it would be relevant to study the impact of regional economic cooperation on the organisation and boundaries of the Southern firm in the wake of Antràs and Helpamn (2004). The authors combine within-sectoral heterogeneity of Melitz (2003) with the structure of firms in Antràs (2003) to deal with issues related to firms' decision of whether to integrate into the production of intermediate inputs or outsource them. Only the case where differentiated final products are developed in the North is taken into consideration, while the South can only produce intermediate goods. However, by also considering the possibility of producing final goods in the South, a similar framework would be appropriate to deal with issues related to the organization of production chains in Southern regions. This would allow to shed more light on an issue that appears to be a major political and eventually business concern, as suggested by the MERCOSUR experience.

Our model looks at preferential regional trade agreements from a slightly different angle than the existing related literature does. Thus, the second, and more

\footnotetext{
${ }^{11}$ Falvey, Greenaway and Yu (2004) construct a two-sector model -one a-la Melitz, one perfectly competitive- with Ricardian comparative advantage and show that the results derived by Melitz (2003) for the imperfectly competitive sector remain essentially the same. Comparative advantage is driven by the stochastic ranking of countries productivity distribution. However, only the production of final goods is considered.
} 
obvious avenue for further work in this area, is to look for empirical evidence, which is surprisingly thin given all the hypes in international policy circles. We are currently gathering data to check whether the logic for which we have provided some theoretical rationale is borne out in the data.

\section{Acknowledgments}

We are grateful to Richard Baldwin for discussions and suggestions. The opinions expressed in this paper are those of the authors and do not necessarily reflect the views of thier respective institutions or its members.

Received 1 February 2005, Accepted 7 December 2005

\section{References}

Antràs, P., 2003. Firms, Contracts, and Trade Structure. Quarterly-Journal-of-Economics 118(4), pp. 1375-1418.

Antràs, P., Helpman, E., 2003. Global Sourcing. Journal of Political Economy 112(3), pp. 552-80.

Aw, B. Y., Chung S., Roberts M. J., 2001. Firm-Level Evidence on Productivity Differentials, Turnover and Exports in Taiwanese Manufacturing. Journal of Development Economics 66(1), pp. 51-86.

Baldwin, R. E., 1988. Hysteresis in Import Prices: The Beachhead Effect. American Economic Review 78(4), pp 773-785.

Baldwin, R. E., Robert-Nicoud, F., 2006. Trade and growth with heterogeneous firms, processed.

Baldwin, R.E., Forsild, R., Martin, P., Ottaviano, G., and Robert-Nicoud, F., 2003. Economic Geography and Public Policy. Princeton University Press.

Baldwin, R. E., Robert-Nicoud, F., 2000. Free Trade Agreements without Delocation. Canadian Journal of Economics 33(3), pp. 766-86.

Bernard A.B., Jensen J.B., 1999a. Exceptional Export Performance: Cause, Effect or Both? Journal of International Economics 47, pp. 1-25.

Bernard A.B., Jensen J.B., 1999b. Exporting and Productivity. National Bureau of Economic Research Working Papers No.7135.

Cernat, L., Laird, S., Turrini, A., 2003. Back to Basics: Market Access Issues in the Doha Agenda. Policy Issues in International Trade and Commodities, UNCATD, Geneva.

Clerides, S. K., Lack, S., Tybout, J. R., 1998. Is Learning By Exporting Important? Microdynamic Evidence from Colombia, Mexico and Morocco. The Quarterly Journal of Economics 113, pp. 903-947.

Dixit A. K., Stiglitz, J. E., 1977. Monopolistic Competition and Optimum Product 
Diversity. American Economic Review, 67(3), pp. 297-308.

Das, S., Roberts, M. J., Tybout J. R., 2001. Market Entry Costs, Producer Heterogeneity, and Export Dynamics. NBER Working Paper No. 8629.

Eaton, J., Kortum, S., 2002. Technology, Geography, and Trade. Econometrica 70(5), pp. 1741-79.

Ethier W. J., 1982, "Decreasing Costs in International Trade and Frank Graham's Argument for Protection", Econometrica, 50(5), pp. 1243-1268.

Flam, H., Helpman, E., 1987. Industrial Policy under Monopolistic Competition. Journal of International-Economics 22(1/2), pp. 79-102.

Ethier, W. J., 1982. Decreasing Costs in International Trade and Frank Graham's Argument for Protection. Econometrica, 50(5), pp. 1243-1268.

Flam and Helpman, 1987, "Vertical Product Differentiation and North-South Trade", American Economic Review 77(5), pp. 810-22.

Fujita, Krugman, P., Venables, A.J., 1999. The spatial economy: Cities, regions, and international trade. MIT Press, Cambridge and London.

Hahn C. H., 2004. Exporting and Performance of Plants: Evidence from Korean Manufacturing. NBER Working Paper No. 10208.

Hallward-Driemerier, M., Iarossi, G., Sokoloff, K.L., 2002. Exports and Manufacturing Productivity in East Asia: A Comparative Analysis with Firm-Level Data. National Bureau of Economic Research Working Papers No. 8894.

Helpman, H., Krugman, P., 1989. Trade policy and market structure. MIT Press, Cambridge and London.

Helpman, H., Melitz M., Rubinstein, 2004. Trading partners and trading volumes. Unpublished manuscript, Harvard University and Tel Aviv University.

Helpman, H., Melitz, M., Yeaple, S. R., 2004. Export versus FDI with Heterogeneous Firms. American Economic Review, 94(1), pp. 300-316.

Hopenhayn, H., 1992. Entry, exit and firm dynamics in long run equilibrium. Econometrica 60, 1127-1150.

Krugman, P., 1980. Scale Economies, Product Differentiation, and the Pattern of Trade. American Economic Review 70(5), pp. 950-959.

Madani, D. H., 2001. Regional Integration and Industrial Growth in Developing Countries: The Case of Three ASEAN Members. The World Bank Policy Research Working Paper Series No. 2697.

Melitz, M., 2003. The Impact of Trade on Intra-Industry Reallocations and Aggregate Industry Productivity. Econometrica 71, pp 1695-1725.

Muendler, M. A., 2004. Trade, Technology, and Productivity: A Study of Brazilian Manufacturers, 1986-1998. University of California at San Diego, Economics Working Paper Series: 2004-06.

Pavcnik, N., 2002. Trade Liberalization, exit, and Productivity Improvements: Evidence fro m Chilean Plants. The Review of Economic Studies 69, pp. 245-276.

Puga, D., Venables, A.J., 1998. Trading Arrangements and Industrial Development, The World Bank Economic Review 12(2), pp. 221-49. 
Puga, D., Venables, A. J., 1999. Agglomeration and Economic Development: Import Substitution vs. Trade Liberalisation. Economic-Journal 109(455), pp. 292-311.

Roberts M. J., Tybout J. R.,1997. The Decision to Export in Colombia: An empirical Model of Entry with Sunk Costs. American Economic Review 87(4), pp. 545-564.

Samuelson, P., 1954. The transfer problem and transport costs, II: Analysis of effects of trade impediments. Economic Journal 64, pp. 264-289.

Soloaga, I.,Winters, A., 2001. Regionalism in the Nineties: What Effect on Trade? NorthAmerican Journal of Economics and Finance. 12(1), pp.1-29.

Sanguinetti, P., Traistaru, I., Volpe Martincus, C., 2004. The Impact of South-South Preferential Trade Agreements on Industrial Development: An Empirical Test.

Tybout, J., 2000. Manufacturing firms in developing countries: How well do they do and why? Journal of Economic Literature 38, pp. 11-44.

UNCTAD, 2004. "The São Paulo Consensus". TD/410, United Conference on Trade and Development, Geneva.

UNCTAD, 2004. UNCTAD Handbook of Statistics, United Conference on Trade and Development, Geneva.

Van Biesebroeck, J., 2003. Exporting Raises Productivity in Sub-Saharan African Manufacturing Plants. National Bureau of Economic Research Working Papers No. 10020.

Venables, A.J., 1987. Trade and trade policy with differentiated products : A Chamberlinian-Ricardian model. Economic Journal 97, pp. 700-717.

Venables, A.J.,1996. Equilibrium location of vertically linked industries. International Economic Review 37, pp. 341-359.

Venables, A.J, 2003. Winners and losers from regional integration agreements. Economic Journal 113 , pp. 747-761.

The World Bank. 2004. Global Economic Prospects 2005. The World Bank. Washington D.C..

Yaşar, M., Nelson, C. H., 2003. The Relationship between Exports and Productivity at the Plant-level in the Turkish Apparel and Motor Vehicle Parts Industries. Unpublished Manuscript Emory University. 